Revue bibliographique pour le domaine irano-aryen

\title{
Mohammad-Taqi Imanpour. "Re-establishement of Achaemenid History and its Development in the Nineteeth and Twentieth Centuries"
}

\section{Rémy Boucharlat}

\author{
(2) OpenEdition \\ Journals \\ Édition électronique \\ URL : http://journals.openedition.org/abstractairanica/46791 \\ DOI : 10.4000/abstractairanica.46791 \\ ISBN : 1961-960X \\ ISSN : 1961-960X \\ Éditeur : \\ CNRS (UMR 7528 Mondes iraniens et indiens), Éditions de l'IFRI
}

\section{Référence électronique}

Rémy Boucharlat, « Mohammad-Taqi Imanpour. "Re-establishement of Achaemenid History and its Development in the Nineteeth and Twentieth Centuries" », Abstracta Iranica [En ligne], Volume 37-38-39 | 2018, document 89, mis en ligne le 30 décembre 2018, consulté le 27 septembre 2020. URL : http://journals.openedition.org/abstractairanica/46791 ; DOI : https://doi.org/10.4000/ abstractairanica.46791

Ce document a été généré automatiquement le 27 septembre 2020.

Tous droits réservés 


\title{
Mohammad-Taqi Imanpour. "Re- establishement of Achaemenid History and its Development in the Nineteeth and Twentieth Centuries"
}

\author{
Rémy Boucharlat
}

\section{RÉFÉRENCE}

Mohammad-Taqi Imanpour. "Re-establishement of Achaemenid History and its Development in the Nineteeth and Twentieth Centuries", Iranian Studies 48/4, 2015, p. 515-530

L'A. donne de l'histoire des recherches sur l'empire achéménide une vision très iranocentriste et néglige des pans entiers de la recherche. Il reconnaît le rôle décisif des Achaemenid Workshops des années 1980-1990, initiés et animés, il le souligne avec justesse, par des historiens tous issus du monde classique. Par ailleurs, il ne fait aucune mention des historiens des langues cunéiformes dont le nombre et les publications ont été exponentiels depuis les années 1980. Le panorama archéologique qu'il offre reste concentré sur l'Iran. Ainsi, les recherches archéologiques ne mentionnent que les sites iraniens, puis l'arrêt des fouilles avec des étrangers de 1979 (qui ont repris vers 2000) marque l'arrêt de sa description. Il n'y a rien sur les recherches archéologiques en Turquie, Levant, Asie centrale ou Egypte. 


\section{AUTEURS}

\section{RÉMY BOUCHARLAT}

UMR 5133 CNRS-Université de Lyon 